\title{
РОЛЬ ПРОФІЛАКТИЧНО-ЛІКУВАЛЬНИХ ЗАХОДІВ У ПРОФЕСІЙНІЙ АДАПТАЦІЇ МОЛОДИХ ФАХІВЦІВ ДО УМОВ ПРОФЕСІЙНОЇ ДІЯЛЬНОСТІ
}

\author{
М. В. Московко, О. Ю. Азархов ${ }^{1}$, С. В. Тимчик, М. Т. Бондарчук ${ }^{2}$ \\ Вінницький національний технічний університет, пУ "Санаторій “Металург”, \\ Міністерство внутрішніх справ України ${ }^{2}$
}

У статті розглянуті роль і функції профілактично-лікувальних заходів у відборі, супроводженні та становленні молодих фахівців, які приходять на роботу в різних сферах професійної діяльності. Обґрунтовано значення профрілактично-лікувального супроводження у формуванні фахівців із високою професійною компетенцією.

Ключові слова: профілактично-лікувальні заходи, адаптація, професійна компетенція, медичне супроводження.

\section{РОЛЬ ПРОФИЛАКТИЧЕСКИ-ЛЕЧЕБНЫХ МЕРОПРИЯТИЙ В ПРОФЕССИОНАЛЬНОЙ АДАПТАЦИИ МОЛОДЫХ СПЕЦИАЛИСТОВ К УСЛОВИЯМ ПРОФЕССИОНАЛЬНОЙ ДЕЯТЕЛЬНОСТИ}

\author{
М. В. Московко, А. Ю. Азархов ${ }^{1}$, С. В. Тымчик, Н. Т. Бондарчук ${ }^{2}$ \\ Винницкий национальный технический университет, чу "Санаторий "Метамург” 1, \\ Министерство внутренних дел Украины ${ }^{2}$
}

\begin{abstract}
В статье рассмотрены роль и функции профилактически-лечебных мероприятий при отборе, сопровождении и становлении молодых специалистов, которые приходят на работу в разных сферах профессиональной деятельности. Обосновано значение профилактически-лечебного сопровождения при формировании высокой профессиональной компетенции работников.
\end{abstract}

Ключевые слова: профилактически-лечебные меры, адаптация, профессиональна компетенция, медицинское сопровождение.

\section{ROLE OF PREVENTIVE AND CURATIVE MEASURES IN PROFESSIONAL ADAPTATION OF YOUNG EMPLOYEES IN THEIR PROFESSIONAL ACTIVITY}

\author{
M. V. Moskovko, O. Yu. Azarkhov', S. V. Tymchyk, M. T. Bondarchuk ${ }^{2}$ \\ Vinnytsia National Technical University Private Sanatorium "Metalurh"1 \\ 2Ministry of Internal Affairs of Ukraine
}

\footnotetext{
The article adduces the role and functions of preventive and curative measures in the selection, maintenance and formation of young professionals who come to work in different professional fields. The significance of preventive and therapeutic support in the formation of high professional competence of employees is substantiated.
}

Key words: preventive and curative measures, adaptation, professional competence, medical support.

Вступ. Щороку в Україні закінчують вищі навчальні заклади тисячі молодих фахівців, які приходять на зміну старому поколінню на виробництво, в медичні заклади, установи освіти, соціальну сферу, правоохоронні органи тощо. При цьому вважається, що кожна особистість являє собою цілісну ієрархічну структуру, яка обумовлена такими компонентами [ 1]: мотиваційними, орієнтаційними, операційними, вольовими й оціночними. Критерієм, який визначає загальну спроможність фахівця до професійної діяльності, можна вважати рівень адаптації до умов службової діяльності.

Тому проблема забезпечення професійної адаптації молодих фахівців до службової діяльності є актуальною і такою, що потребує вирішення.

Метою даної роботи $є$ обгрунтування необхідності участі профілактично-лікувальних заходів у професійному відборі і супроводженні молодих фахівців на початку їх професійної діяльності та визначення 
основних завдань цих заходів у процесі становлення молодого професіонала.

Постановка проблеми. Психологічний аспект адаптації полягає в пристосуванні людини як особистості до існування в середовищі професійної діяльності, що має надзвичайно складну структуру в якій, окрім усвідомлюваних факторів, існує велика різноманітність неявних, але реальних складників. У певних складних ситуаціях, якими сьогодні насичена практично будь-яка професійна діяльність, умови середовища можуть мати вирішальний вплив на виконання поставленого завдання [2].

Професійна адаптація - це пристосування людини до нових для неї умов праці, оволодіння особистістю ціннісними орієнтаціями в межах професії, усвідомлення основних мотивів та головної мети в новій для індивіда діяльності, зближення внутрішніх суб'єктивних норм людини та професійної групи, засвоєння основних компонентів професійної діяльності (завдань, способів, засобів, результатів та умов).

При зміні однієї з цих умов відбувається перебудова адаптаційних механізмів з урахуванням більш високих вимог, які висуваються до індивіда середовищем, що його оточує.

Без професійної адаптації неможливе забезпечення професійної надійності персоналу, яка полягає у здатності працівників впевнено, успішно та ефективно, 3 дотриманням вимог чинного законодавства та службової дисципліни, виконувати свої функціональні обов 'язки як за звичних умов професійної діяльності, так і за екстремальних умов.

Професійна адаптація молодого фахівця виявляється у його пристосуванні та звиканні до характеру, режиму та умов праці, у певному рівні оволодіння фаховими знаннями, вміннями та навичками, у формуванні необхідних професійних якостей особистості, які потрібні для успішного оволодіння даною спеціальністю і включає в себе такі компоненти, як адаптація до змісту діяльності, до умов діяльності, до службового колективу, до стосунків з керівництвом, включення в первинну (малу) групу колег та в процеси саморозвитку (розвиток мотивації, оволодіння професійними знаннями, становлення професійних вмінь, навичок і тощо).

Відсутність хоча б одного з компонентів призводить до порушення цілісності всього процесу і не дозволяє говорити про успішність адаптації в цілому та може в подальшому призводити до низької ефективності та якості виконання професійної діяльності.

Результати дослідження та їх обговорення. Одним із найбільш ефективних і дієвих підходів до забезпечення належного рівня професійної адаптації $\epsilon$ комплекс лікувально-профілактичних заходів, що передбачають поєднання форм і методів лікувальної та профілактичної роботи. При організації слід враховувати, що психосоматична патологія - це соматичні захворювання людини, які пов'язані із психологічними або патопсихологічними змінами особистості і через перевантаження. У багатьох випадках загострення соматичних захворювань настає після чергової емоційно-стресової ситуації. Розвиток психосоматичних захворювань обумовлюється комплексом причин, в тому числі дією психотравматичних факторів. Навіть найменші порушення психічної діяльності, що можуть виникати у молодих фахівців, потенційно здатні призвести до тяжких наслідків, у тому числі й до виникнення автоагресивних тенденцій.

У зв'язку з цим основним завданням лікувальнопрофілактичних закладів є:

- відбір кандидатів на роботу за станом здоров'я та індивідуальними психофізіологічними особливостями;

- психотерапевтична допомога та реабілітація працівників, які отримали посттравматичні стресові розлади;

- виявлення психічних порушень на ранніх етапах їх виникнення;

- надання адекватної лікувальної допомоги;

- медико-психологічна та психіатрична реабілітація працівників, які хворіють;

- проведення роз'яснювальної роботи про шкідливу дію на організм людини куріння, зловживання алкоголем та психічно активними речовинами.

Для успішного вирішення проблем ранньої діагностики станів психоемоційного напруження, психічних розладів необхідне проведення щорічних медичних профілактичних оглядів, скринінгових обстежень, головною метою яких повинно бути визначення наявності (відсутності) психічних розладів у молодих фахівців.

Щодо працівників, діяльність яких пов'язана з екстремальними умовами, осіб, віднесених до групи посиленої психологічної уваги, суб'єктів із вираженими ознаками професійної деформації та девіантної поведінки, дезадаптивними психологічними станами, працівників, які зазнали психотравматичного впливу за умов добровільної згоди й дотримання чинного законодавства, можливе здійснення спеціалізованих, поглиблених психодіагносгичних та психокорекційних заходів.

Висновки. Об'єднання зусиль керівника, наставника, працівників кадрового апарату, психолога та адек- 
ватне планування процесу адаптації молодого працівника до умов професійної адаптації дозволяє, з одного боку, зменшити можливість появи помилок, невдоволення, розчарувань, які пов'язані з першими кроками в службовій діяльності та можуть в подальшому при-

\section{Лiтература.}

1. Дьяченко М. И. Психологические проблемы готовности к деятельности / М. И. Дьяченко, Л. А. Кандибович. Минск: Изд-во БГУ 1967. - 176 с.

2. Аналіз структури психологічної готовності молодих офіцерів Збройних Сил України до професійної діяльності (за звести до проявів негативних явищ (пияцтва, професійної деформації), а з іншого боку сприяє зниженню плинності кадрів, покращенню професійної підготовки персоналу, забезпеченню професійної та соціальнопсихологічної надійності молодого фахівця.

матеріалами літературних джерел) / [Коваль Л. Г., Злепко С. М. Костішин С. В. та ін.] //Вимірювальна та обчислювальна техніка в технологічних процесах. - 2012. - № 2. C. 111-115. 